\title{
Energy potential from biomass wastes analysis at the regional level
}

\author{
Tatiana I. Andreenko ${ }^{1}$ and Tatiana S. Gabderakhmanova, ${ }^{2, *}$ \\ ${ }^{1}$ Lomonosov MSU, Leninskie gory 1, Moscow, Russia \\ ${ }^{2}$ Russian Academy of Science Joint Institute for High Temperatures, Russia
}

\begin{abstract}
The paper presents a methodical approach to step-by-step analysis of the agricultural waste resource potential for energy-deficient territories. On an example of model region of Russia (the Volgograd area) the estimation of agroindustrial complex waste energy potential showed that technical potential of waste only in the plant growing of the region is 10 times higher than the consumption of electricity by the rural areas of the region. In addition, the transformation of chemical bonds of crop waste into electrical energy could prevent the release of 1.86 million tons of $\mathrm{CO}_{2}$ per year for the region.
\end{abstract}

\section{Introduction}

An enormous amount of organic waste is generated every year worldwide - wastes from agriculture (crop and livestock), municipal wastes, etc. Its harmful impact on the environment can not be overlooked and rely on their natural assimilation without human intervention. At the same time, the development of technologies has led to the fact that these wastes become a source of raw materials for processing and obtaining valuable products. The experience of many countries has shown that the processing of organic waste with energy production is exceptionally promising. By this we can solve two problems: energy production and waste disposal, which is very important for a wide range of regions, including those remote from centralized power supply where the use of traditional energy sources is impossible or inconvenient.

Due to the fact that waste management in general and the processing of organic waste for energy production in particular are significant problems for many countries in the world, a great number of studies in the field of renewable energy are devoted to optimizing the placement of organic waste processing systems in a given territory in the presence of distributed sources waste. The methods of using geoinformational systems (GIS) tools to optimize the territorial schemes for processing organic waste at the regional level are a relevant area of research [1-3]. In the work [4] is presented a GIS-approach for assessing the potential of biogas production from livestock and crop waste on a regional scale, where approbation of methods was carried out on the example of the territory of the KujawskoPomorskie Province (Poland). The method is developed using ARCGIS 9.3 software, considering spatial distribution of raw materials and territorial environmental and technical

\footnotetext{
*Corresponding author: tatagabderakhmanova@yandex.ru
} 
aspects. This instrument allows to visually analyze simultaneously different types of waste and their spatial distribution.

During last ten-year period a number of studies is devoted to quantitative assessments and analysis of organic waste sources territorial distribution that are considered as raw materials for energy production. On the basis of data on the amount and structure of waste, as well as modern technologies for obtaining energy from biomass, electricity and heat are calculated, as well as an estimation of projects profitability. Since these studies need to take into account various geographically related objects and factors, GIS technologies are used as a research tool [5-7].

Russia also has accumulated some experience in integral estimations of the gross resource and technical potential of the wastes biomass on the national level of research [8, 9]. But there are no developed approaches and no methods for the assessment of waste generated at the municipal level. Therefore, this work shows the implementation of the first methodology stage: the assessment of the energy potential of crop and livestock wastes with detailed elaboration to municipal districts and their cartographic representation.

\section{Methodology}

In connection with the need to take into account the specific features of the formation of various types of waste and the difference in their specific energy content, calculations of waste values and their energy potential have been carried out separately: in crop production, for individual types of crops, and in livestock for different types of livestock and poultry.

Based on the generally accepted approach for determining the energy contained in waste biomass, waste mass values $\left(M_{i}\right)$ and their specific energy content (or lower heating value) of the relevant biomass species. The mass of annually generated organic waste was calculated using the statistical data of the annual crops or livestock $\left(N_{i}\right)$ on the basis of experimentally defined rates of waste generation or ratios $\left(L_{i}\right)$ :

$$
M_{i}=N_{i} * L_{i}
$$

Here $i$ is the type of plant cultures and (or) the type of animal breeding.

On the basis of the mass determined in this way, the energy potential of the waste $\left(Q_{i}\right)$ was calculated as the product of the waste mass $\left(M_{i}\right)$ and lower heating value $K_{i}$ :

$$
Q_{i}=M_{i}^{*} K_{i}
$$

The following official data of the Russian Federal State Statistics Service were used for calculations: annual data on gross harvest of the leading crops and livestock in the main livestock areas of the region. When calculating the energy potential of agricultural waste, the waste generated in the households was not taken into account because of the impossibility of its collecting. In this connection, the characteristic "available gross potential of agricultural waste" was introduced, which implies the energy content of all organic wastes of crop production and animal husbandry, in addition to waste generated in the households.

As waste processing technologies, it was considered the production of electricity and heat using mini thermal power plants (mini-TPPs) with direct combustion of biomass (for crop waste) or mini-TPPs on biogas (for livestock wastes). For mini-TPPs with direct combustion of biomass waste energy efficiency of power plant is $35 \%$, station service consumption is $3 \%$. For mini-TPPs in biogas it is $80 \%$ and $14 \%$ respectively. The obtained estimates of the bioenergy potential are presented in the form of tables and maps. 


\section{Results}

The Volgograd region is one of the largest producers of agricultural products in the Russian Federation, in its production structure, about $70 \%$ is crop production. The basic branch of agriculture in the region is the production of grain, the second crop in terms of the area of crops is sunflower. In the Volgograd region, these crops are grown everywhere, but areas with maximum yield are located in the north and north-west of the region. The corresponding available gross energy potential of the wastes of production of the above crops is presented in Table 1 and in Figure 1.

Table 1. Energy content of cereal and sunflower production waste in the municipal formations of the Volgograd region on average for 2013-2014 (leaders among the regions in terms of gross harvest and energy potential of waste), tons of coal equivalent (TCE).

\begin{tabular}{|c|c|c|c|c|c|c|c|}
\hline \multirow{3}{*}{\begin{tabular}{|} 
\\
$\begin{array}{c}\text { Municipalities } \\
\text { (districts and city } \\
\text { districts) }\end{array}$
\end{tabular}} & \multicolumn{7}{|c|}{ Name of plant culture } \\
\hline & \multicolumn{2}{|c|}{$\begin{array}{l}\text { Waste of } \\
\text { cereals } \\
\text { (straw) }\end{array}$} & & \multicolumn{4}{|c|}{ Waste from sunflower production } \\
\hline & $\begin{array}{c}\text { Was } \\
\text { te, } \\
10^{3} \\
\text { t/ } \\
\text { year }\end{array}$ & $\begin{array}{c}\text { Energy } \\
\text { of } \\
\text { waste, } \\
10^{3} \text { tce/ } \\
\text { year }\end{array}$ & $\begin{array}{l}\text { Municipalities } \\
\text { (districts and } \\
\text { city districts) }\end{array}$ & $\begin{array}{c}\text { Yield } \\
\text { of } \\
\text { seeds, } \\
10^{3} \mathrm{t}\end{array}$ & $\begin{array}{c}\text { Waste } \\
\text { (stems), } \\
10^{3} \text { tce/ } \\
\text { year }\end{array}$ & $\begin{array}{c}\text { Waste } \\
\text { (husk), } \\
10^{3} \text { tce/ } \\
\text { year }\end{array}$ & $\begin{array}{l}\text { Waste (in } \\
\text { general), } \\
10^{3} \text { tce }\end{array}$ \\
\hline Kotovsky & 321 & 136 & $\begin{array}{l}\text { Novonikolaev } \\
\text { sky }\end{array}$ & 114 & 183 & 11 & 194 \\
\hline Novoanninsky & 238 & 101 & Novoanninsky & 97 & 155 & 9 & 164 \\
\hline Yelanskiy & 217 & 92 & Yelanskiy & 89 & 143 & 9 & 151 \\
\hline Novonikolaevsky & 211 & 90 & Uryupinskiy & 83 & 133 & 8 & 141 \\
\hline Uryupinskiy & 206 & 89 & Kikvidzenskiy & 64 & 103 & 6 & 109 \\
\hline Mykhailivka & 205 & 87 & Mykhailivka & 53 & 85 & 5 & 90 \\
\hline Kletsky & 186 & 79 & Zhirnovsky & 42 & 66 & 4 & 70 \\
\hline Oktyabr'skiy & 172 & 73 & Nekhayevskiy & 40 & 63 & 4 & 67 \\
\hline Kikvidzenskiy & 162 & 69 & Rudnyansky & 34 & 54 & 3 & 57 \\
\hline Chernyshkovsky & 153 & 65 & Danilovsky & 31 & 50 & 3 & 53 \\
\hline Danilovsky & 134 & 57 & Alekseevsky & 30 & 48 & 3 & 51 \\
\hline Kotelnikovsky & 132 & 56 & \multirow{5}{*}{$\begin{array}{l}\text { The rest } \\
\text { municipalities }\end{array}$} & \multirow[t]{5}{*}{28} & \multirow{5}{*}{ a } & \multirow{5}{*}{ less } & \multirow[t]{5}{*}{5} \\
\hline Seraphimovichi & 126 & 54 & & & & & \\
\hline Alekseevsky & 121 & 52 & & & & & \\
\hline Nekhayevskiy & 117 & 50 & & & & & \\
\hline $\begin{array}{l}\text { The rest } \\
\text { municipalities }\end{array}$ & $\begin{array}{l}116 \\
\text { and } \\
\text { less }\end{array}$ & $\begin{array}{l}49 \text { and } \\
\text { less }\end{array}$ & & & & & \\
\hline Total: & $\begin{array}{c}350 \\
1\end{array}$ & 1488 & & 756 & 1187 & 67 & 1254 \\
\hline
\end{tabular}

17 districts of the region obtain grain yields of more than 1 million centners, which corresponds to the waste energy content of more than $42.5^{*} 10^{3}$ tons per year for each district. In 9 districts the gross grain harvest exceeds $1.5^{*} 10^{6}$ centners, and in 4 regions grain harvest was higher than 2 million centners. Respectively, energy content of cereal waste exceeds $63.8 * 10^{3}$ tons of coal equivalent and $85^{*} 10^{3}$ tons of coal equivalent.

As can be seen from Table 1, sunflower production waste in Volgograd region is significant and its total energy content is only $15.7 \%$ less than the energy content of cereals wastes. In calculations of the gross energy potential of sunflower waste it was assumed that the yield of stalks and baskets is 35\% of the crop mass, and husks are $18 \%$. The calorific value of air-dried waste with humidity of $18-20 \%$ (for sunflower stems) is $3200 \mathrm{kcal} / \mathrm{kg}$, for husks - $3750 \mathrm{kcal} / \mathrm{kg}$ [10]. These characteristics make it possible to carry out a 
differentiated assessment of the energy content for stems and husks: $1187 * 10^{3}$ tons and $67 * 10^{3}$ tons respectively. This clarification has a fundamental importance, since processing into energy implies the use of various technologies and is geographically dispersed.

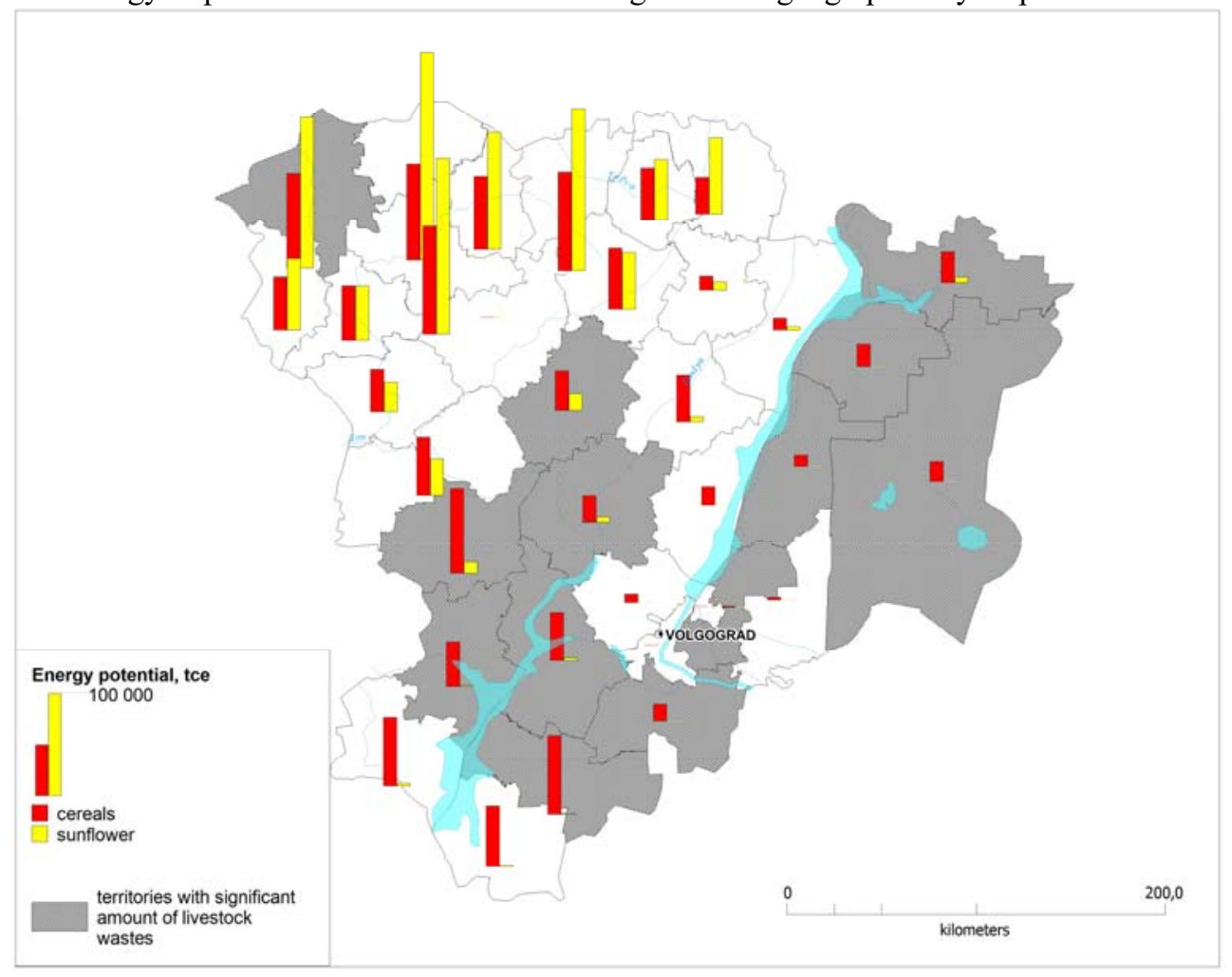

Fig. 1. The map of bioenergy resources spatial distribution.

The main directions of livestock breeding in the Volgograd region are: breeding of cattle, poultry breeding, pig breeding, sheep and goat breeding. It is important to note that the private farms in this region grow most of the livestock population. Nevertheless estimation of the resources and available livestock wastes gross energy potential was calculated only for the number of animals and poultry farmed in a big agricultural organizations and peasant farms, the waste of which can be collected easily. Therefore, the energy potential of livestock waste in the region is much less than the same from crop production.

Figure 1 shows areas with significant values of the energy potential of livestock waste. As can be seen, the central and eastern districts of the region have the greatest potential for bioenergy. As it was mentioned above we assessed the amount of electrical and thermal energy, which can be obtained from available for processing organic waste. The results of the evaluations are presented in Table 2.

According to the Federal State Statistics Service $331.5^{*} 10^{6} \mathrm{kWh}$ of electricity was used in agriculture in the Volgograd region during 2014. As it could be seen from our data (Table 2), the technical potential of electricity from plant waste in this region is $3408 * 10^{6}$ $\mathrm{kWh}$. So this amount is 10 times higher than the consumption of electricity in agriculture throughout the region.

However, for the Volgograd region, the most profitable use of crop waste is heating by its burning in municipal boiler houses. In 2014 Volgograd region produced $17024.7^{*} 10^{3}$ Gcal of heat. The rural population is about one-fourth of the region's population. Assuming 
that the same amount of heat is consumed per capita in rural and urban areas, we find that $71.7 \%$ of heat demand in rural areas can be provided by the thermal technical energy potential of crop waste.

Table 2. Technical potential of livestock and crop wastes of municipal districts and urban districts of Volgograd region.

\begin{tabular}{|c|c|c|c|c|c|}
\hline $\begin{array}{l}\text { Municipalities } \\
\text { (districts and city } \\
\text { districts) }\end{array}$ & $\begin{array}{l}\text { Technical } \\
\text { potential of } \\
\text { crop waste } \\
\text { in general, } \\
\text { electricity, } \\
10^{6} \mathrm{kWh}\end{array}$ & $\begin{array}{l}\text { The } \\
\text { technical } \\
\text { potential } \\
\text { of crop } \\
\text { waste in } \\
\text { general, } \\
\text { thermal } \\
\text { energy, } \\
10^{3} \mathrm{Gcal}\end{array}$ & $\begin{array}{l}\text { Municipalities } \\
\text { (districts and city } \\
\text { districts) }\end{array}$ & $\begin{array}{l}\text { Technical } \\
\text { potential of } \\
\text { livestock } \\
\text { wastes in } \\
\text { general, } \\
\text { electricity, } \\
10^{6} \mathrm{KWh}\end{array}$ & $\begin{array}{c}\text { Technical } \\
\text { potential } \\
\text { of } \\
\text { livestock } \\
\text { wastes in } \\
\text { general, } \\
\text { thermal } \\
\text { energy, } \\
10^{3} \text { Gcal }\end{array}$ \\
\hline Novonikolaevsky & 661 & 1151 & Gorodishchensky & 21 & 36 \\
\hline Novoanninsky & 593 & 1033 & Svetloyarskiy & 18 & 31 \\
\hline Yelanskiy & 544 & 949 & Novonikolaevsky & 15 & 26 \\
\hline Uryupinskiy & 511 & 891 & Sredneakhtubinsky & 14 & 24 \\
\hline Kikvidzenskiy & 397 & 691 & Pallasovsky & 12 & 21 \\
\hline Mykhailivka & 369 & 643 & Ilovlinsky & 11 & 20 \\
\hline Nekhayevskiy & 254 & 443 & Surovikinsky & 9 & 15 \\
\hline Zhirnovsky & 242 & 421 & Uryupinskiy & 7 & 13 \\
\hline Rudnyansky & 225 & 393 & Frolovsky & 7 & 13 \\
\hline Danilovsky & 225 & 393 & Oktyabr'skiy & 7 & 12 \\
\hline Alekseevsky & 213 & 371 & Staropoltavsky & 7 & 12 \\
\hline Seraphimovich & 171 & 299 & Kalachevsky & 7 & 12 \\
\hline Kletsky & 137 & 239 & Kletsky & 6 & 11 \\
\hline Kumylzhensky & 131 & 229 & Bykovsky & 6 & 10 \\
\hline \multirow{2}{*}{ The rest municipalities } & 104 & 181 & \multirow{3}{*}{$\begin{array}{l}\text { The rest } \\
\text { municipalities }\end{array}$} & 3 & 5 \\
\hline & \multicolumn{2}{|c|}{ And less } & & \multicolumn{2}{|c|}{ And less } \\
\hline Total: & 3408 & 5939 & & 106 & 184 \\
\hline
\end{tabular}

The ecological effect of using crop wastes for electricity and heat production was estimated as an amount of the prevented $\mathrm{CO}_{2}$ emissions. The average specific $\mathrm{CO}_{2}$ emission from fuel power station on natural gas in Russia is $547 \mathrm{~g} \mathrm{CO}_{2} / \mathrm{kW}^{*} \mathrm{~h}$ [11]. One combined heat plant spends $0.3 \mathrm{~kg}$ of coal for the production of $1 \mathrm{kWh}$ of electric power. Taking into account the calculated amount of electric energy from crop waste in Volgograd region the prevention of $\mathrm{CO}_{2}$ emissions can be about 1.86 million tons of $\mathrm{CO}_{2}$ per year.

\section{Conclusions}

The first stage of approbation of the methodology for assessing the energy potential of agricultural wastes revealed, first of all, significant volumes of the energy potential of agricultural waste in the studied region. The analysis showed uneven distribution of different types of biomass wastes, which is undoubtedly associated with agroclimatic conditions, land use peculiarities, specificity of population distribution, etc. It is shown that 
a significant number of northern and western regions of the region have a large energy potential of cereal and sunflower waste, and areas of the interfluve and the left bank of the Volga (Gorodishchensky, Svetloyarsky, Bykovsky, Leninsky and Sredneahtubinsky) potato and vegetable waste. Central, eastern and south-eastern regions of the region are characterized by a significant energy potential of livestock wastes.

The calculations of the technical energy potential of the waste biomass allow to determine the amount of electricity and heat that can be obtained from it using modern technologies - mini-TPP with direct combustion of biomass or mini-TPP on biogas for livestock wastes.

Analysis of agricultural production trends in the region over the past years has shown that the development of the agroindustrial complex of the Volgograd region is of a sustainable nature. This allows us to conclude that the amount of agricultural waste produced in the Volgograd region can become a reliable source for the production of heat and electricity.

This work was carried out on the state budget theme «Geography and sustainable use of renewable energy sources". Authors acknowledge Yulia Rafikova for mapping results and discussion.

\section{References}

1. S. Dagnall, J. Hill, D. Pegg, Bioresource Technol. 71 (2000)

2. F.A. Batzias, D.K. Sidiras, E.K. Spyrou, Renew. Energ. 30 (2004)

3. A. Gomez, J. Zubizarreta, M. Rodrigues, C. Dopazo, N. Fueyo, Resourc. Conserv. Recy. 54 (2010)

4. B.A. Sliz-Szkliniarz, J. Vogtb, Renew. Sust. Energ. Rev. 16 (2012)

5. A.M. Gormally, J.D. Whyatt, R.J. Timmis, C.G. Pooley, Energ. Policy, 50 (2012)

6. Q. Wang, M. Mwirigi, M’Ikiugu, I, Kinoshita, Sustainability-Basel, 6 (2014)

7. A.W. Bauen, A.J. Dunnett, G.M. Richter, A.G. Dailey, M. Aylott, E. Casella, G. Taylor, BioresourceTechnol. 101 (2010)

8. P.P. Bezrukikh, Spravochnik po resursam vozobnovlyayemykh istochnikov energii Rossii $i$ mestnym vidam topliva (pokazateli po territoriyam (Moscow, IATS Energiya, 2007)

9. O.V. Danilova, G.V. Ermolenko, S.V. Kiseleva, L.V. Nefedova, O.S. Popel, S.E. Frid, Atlas resursov vozobnovlyayemoy energii na territorii Rossii (Moscow, RKHTU im. D.I. Mendeleyeva, 2015)

10. S.V. Klyus, G.N. Zabarnyy, Kollektornoye i energeticheskoye mashinostroyeniye, 2 (2011)

11. P.P. Bezrukikh, Vetroenergetika (Moscow, 2010) 